\title{
The built memory: presenting the colonization villages in Spain by the newsreel of State NO-DO.
}

\author{
Josefina González Cubero ${ }^{1,1}$, and Alba Zarza Arribas ${ }^{1}$ \\ ${ }^{1}$ University of Valladolid, Escuela Técnica Superior de Arquitectura, Department of \\ Architectural Theory and Projects, Spain
}

\begin{abstract}
The newsreel of State used to show to Spanish society a determined image of architecture, conditioned by the political needs of Franco's Regime. In this case, the subject of the cinematographic image of villages of colonization of the Tagus valley as presented by the NODO newsreel (Noticiarios y Documentales Cinematográficos) is studied. NO-DO was originally created as a propaganda tool and an instrument for the diffusion of "specially relevant" news from that time period.

The analysis of the architecture built by the National Institute of Colonization (INC) and showed in different editions of the newsreel allowed us to understand the ideological approach made by the Regime to the Spanish countryside, through the model of colonization of the territory, and how building was used as propaganda. The urban model proposed was defined by civic centres -usually square-shaped-, and church towers as urban milestones set in the landscape. For this reason, politic demonstrations in the representative public spaces of villages, through the delivering of houses and rural property to settlers, incorporated the context and living conditions in which new villages were built. At the same time, the visits to irrigation farms, new irrigation canals, and hydraulic and hydroelectric infrastructures exemplify the agrarian and irrigation policies during the autarchy, whereas in the next decades, and because of the economic and social development of the countryside, news about reservoirs were just referred to sports and leisure activities. Therefore, these cinematographic images of buildings, irrigation policies and the modernization of rural landscape presented in cinemas through the NO-DO newsreel are relevant, since they build a collective memory of the architecture and engineering of that time. They also document the social, politic and economic role that the creation of Spanish villages of colonization at river basins had, specifically in one of the biggest rivers, the Tagus.
\end{abstract}

\section{Introduction}

This paper is an example of research in which the cinematographic image of architecture is studied though the newsreel of the State NO-DO (Noticiarios $y$

\footnotetext{
${ }^{1}$ Corresponding author: josefina.gonzalez.cubero@tap.uva.es
} 
Documentales Cinematográficos, 1943-1981) ${ }^{2}$, whose screening before the main film was mandatory in every cinema in Spain and its colonies until 1975. As mass media, it was the educative, dissemination, entertainment and propaganda tool of the official production company created (1942) by the Franco dictatorship.

The Spanish newsreel NO-DO adopted a similar format to the ones produced in other countries, as the regularity of appearance, standard duration (10-11 minutes, 300 metres approx., 1 standard film roll) and a sum of diverse news, with two editions of the newsreel produced weekly, reaching three editions during the 1960s.

Thus, the NO-DO newsreel constitutes a historical documentation and an inestimable audiovisual archive, really useful from the architectural perspective as well. Here the new villages also built under the Franco Regime by the Instituto Nacional de Colonización (INC) are addressed, and specifically the ones built in the Tagus river basin. With this example, it is about defining if what has been affirmed so far about the newsreel is scientifically or popular legends based or it corresponds to a partial reading on similar or opposed ideological foundations. For that purpose, three focuses of study are addressed: the newsreel as a whole, the representation of the villages of colonization and the projected and built villages.

\section{The villages and the NO-DO}

The newsreel offered the society of the moment its own consideration of "actuality" with a clear timeless vocation, a feature that grew up over the years. The historical heritage and the coetaneous architecture were not apart from this consideration, with a presence conditioned by the political intentions of the dictatorship in the dissemination of its values, rituals and achievements.

With its specific content characteristics and being a notary of a time, Tranche and Sánchez-Biosca explain that "the newsreel is much closer to which can be defined as a 'informative show' than an assumption 'cinematographic journalism' "3 [1: 83], and they define its main quality: "the banality as a system ${ }^{4}$ " [1:514]. Therefore, it is the result of a number of varied and light pieces of news with message, destined to the population entertainment. Its first director even recognised that: "The Newsreel is no more than a newspaper which higher percentage of readers are in the female public; which is why we devote a special interest in doing it pleasant for the women" [2] ${ }^{5}$.

The important panoramic studies ${ }^{6}$ on NO-DO have not pretended to address all the issues, and certainly not all periods, with the role of the villages of the colonization in the newsreel still remain to be define. However, this cannot be studied today from the same perspective than in the last decades, since it is necessary to do it overcoming

2 The official entity NO-DO, responsible for producing the newsreel and documentaries, depended on the Vicesecretaría de Educación Popular (1946-1951) of the Ministerio de Educación Nacional (1938-1966) and later it was moved on to the Ministerio de Información y Turismo, since its creation (1951).

${ }^{3}$ Translation by the authors: "el noticiario está mucho más cerca de lo que podríamos definir como 'espectáculo informativo' que de un supuesto 'periodismo cinematográfico' ".

${ }^{4}$ Translation by the authors: "la banalidad como sistema".

${ }^{5}$ Translation by the authors: "El Noticiario no es más que un periódico cuyo mayor porcentaje de lectores se encuentra en el público femenino; de ahí que dediquemos un especial interés en hacerlo ameno a las mujeres".

${ }^{6}$ Standing out are the studies of Rafael R. Tranche and Vicente Sánchez-Biosca [1], Saturnino Rodríguez [3] and Araceli Rodríguez [4]. 
ideologies, but without forgetting history. It is indispensable to analyse it from the inside, understanding it as an autonomous document, with its own discourse and determinants, and objectively based in its 1966 editions, namely 4016 numbers developed.

To this end, a methodology has been applied for getting and quantifying the data consistent in: 1- searching for architectonic issues in the table of contents that accompanied the distinct numbers of the newsreel; 2- classifying later in different categories and subcategories according to the architectural typology contained ${ }^{7}$. Some minor variations exist in the quantitative detection of subjects and news because of the difficulties to assign a unique category (by grouping of contents in the same piece of news, by omission of the location or mention of different places, by include different types of buildings, etc.), which does not alter significantly the figures to support the general statements. In the next subcategories, these overlaps are been corrected to achieve greater precision.

In descending order of category ${ }^{8}$, the results are 3076 pieces of news about architecture in general, 201 addressed to the colonization in general, 188 about large hydraulic works and irrigations canals, 24 pieces of news referred to the new villages built by the INC and 6 pieces of news dedicated to the ones in the Tagus river basin. They started with a distribution of farms in Talavera la Vieja in Toledo (1949), although the first reference of villages is with La Rinconada in Seville (1947). The most represented river basin with its settlements is the Guadalquivir one, with 9 news, whereas the Guadiana (Plan Badajoz) and the Ebro ones appear in 4 news each one. The Tagus one has an intermediate relief, with 6 news $^{9}$ from 1949 to 1959 and the show 8 villages of the 33 ones belonging to this basin.

As it is verified, the presence of these villages has more correspondence with the popular mythology than with the reality, maybe because its association with the supremacy of the hydraulic works of the Plan Nacional de Obras Públicas, which have been also magnified in the collective unconscious if the 188 news about them in relation to the total production of the newsreel are considered.

\section{The cinematographic representation of the villages}

The characteristics of the representation of the new Tagus villages in the NO-DO images are common to the rest of news about the ones in the other basins ones. They were reflected practically finished, with their building process missing. The architecture was mainly showed with the emblematic buildings and spaces, emphasising on the churches since religion impregnated all in the Regime and in the NO-DO, and leaving housing as an extra of the previous ones. The authors of the constructive works were not granted any recognition, with the exception of José Luis Fernández del Amo, the only architect identified several times ( $\mathrm{N}^{\circ} 809 \mathrm{~B}, 1958$ and 847A, 1959) as author of the paradigmatic colonization village of Vegaviana in Cáceres.

The shots at street level were frequent, leaving for special occasions the aerial views from the privileged places provided by the bell tower of the church and by the balconies of the town halls. When exceptionally birds-eye views were used, photographs were

\footnotetext{
${ }^{7}$ To choose the categories, the reference has been [5].

${ }^{8}$ Categories: Architecture / Colonization / Hydraulic works / Colonization villages / Tagus river basin.

${ }^{9}$ Of the 6 news, 5 content images about the villages.
} 
normally utilised. Each point of view was associated to one content, although without exclusivity.

The domestic vision at street level reflected the way of life that, in the case of the Tagus, was fundamentally based on the artistic photography because it included the important photographic exhibition of Joaquín del Palacio (Kindel) ${ }^{10}$ about Vegaviana at the Ateneo de Madrid, after its success in Moscow and on its way to Sao Paulo. NODO counted the international recognition of the work, thanks to the photography vehicle, in one of the sporadic news of architecture which opened the newsreel. Fernández del Amo recognised the photographic contribution to the success of the village [7: 191-193], which images have been become icons of the Modern Spanish rural architecture.

The institutionalized vision comprised fleeting fragments of the villages turned into scenographies for the official rituals, contained handovers the keys, as the ones in Alberche del Caudillo in Toledo ( $\left.N^{\circ} 719 \mathrm{~A}, 1956\right)$, and visits of dignitaries, as the one of the United States Secretary of Agriculture to Cortijo de San Isidro in Madrid ( $N^{\circ} 776 \mathrm{~A}$, 1957).

NO-DO was more inclined to show the urban housing on the new city outskirts because of the huge number built against the lower number of the villages. The progress of the modern construction techniques far exceeded the traditional construction systems on the screen as well. Likewise, the visual showiness of all kinds of buildings swept away the quiet and modern simplicity of the new rural buildings; those later aspects were really valued within the professional sphere of architecture. As it is characteristic of its, the newsreel was not letting the images speak out by themselves, anyway they were accompanied by the pompous and vacuous rhetoric of the narrator (voice-over), whose breath impregnated the images being the text the greatest propaganda exponent.

The colonization villages were scarce in the newsreel during the "developmentalism" (desarrollismo), when the Regime turned its gaze to other places as the tourism and big cities, although the hydraulic works remained in the images until the end of its existence, provided by the light-hearted of the leisure practice and sports.

\section{The architecture of the villages}

During the 1940s, the INC raised disseminated (Finca Las Torres, Seville), semigrouped (Poblado El Torno, Cádiz) and grouped (Gimenells, Lérida) housing. Later, with a few exceptions, it decided on the group of the settlers' houses in villages, with right and modern solutions to organization, where "the urban is part of the own control device ${ }^{11 ",}$ according to Oyón Bañales [8: 20]. This author summarized the differences in the urban planning during the 1940s and 1950s: from "the close perspectives, the main streets finished by the tower, the 'main square' (in turbine) and the popular details $^{12, "(i b i d .)}$ to "the freer plannings, the separation of circulations more decided, the volumetric decomposition and the progressive introduction of the void in many public

\footnotetext{
${ }^{10}$ The Revista Nacional de Arquitectura dedicated an extensive article to Vegaviana [6], using the Kindel's photographs after being awarded a prize during the $\mathrm{V}^{\text {th }}$ IUA Congress in Moscow.

${ }^{11}$ Translation by the authors: "lo urbano forma parte del propio dispositivo de control".

${ }^{12}$ Translation by the authors: "las perspectivas cerradas, las calles principales rematadas por la torre, la 'plaza mayor' (en turbina) y los detalles populares".
} 
spaces $^{13 \prime \prime}$ (ibid.). At the same time, he exposed the continuity elements between both decades: "the rational and the serial housing programme ${ }^{14, "}$ (ibid.).

The agricultural engineers decided the establishment of villages according to the territorial transformation of the country; in other words, their creation was not an end in itself but a consequence of the colonization [9]. The temporary cartography (every 5 years) of the Tagus river basin with the villages' locations and how the NO-DO shown them delayed reveals a centrifuge establishment from the capital city (Madrid) to the outermost regions, which proves that the way of operating was a gradual opening of the road to the more uninhabited places.

Since the arrival of José Tamés Alarcón to the leadership of the Servicio de Arquitectura of the INC (1943-1975), the programme and functional guidelines of the villages were established, as the composition unity of the street and block, without proposing mandatory directives to the general organization and residential typologies. Tamés himself defined the conditions of the rural housing [10: 4] and typified examples for different regions ${ }^{15}$. With the objective of beautifying these rural Arcadias, a simplified popular language was used, based on the reinterpretation of recognisable elements of the vernacular architecture of the region, common to the whole village and even area, whose final finalisation was responsibility of the architects who, with reduced resources, achieved a high architectural quality.

The extension of the present paper prevents making reference to the new and interesting publications based on researches about almost 35 new villages. Nevertheless, this is no an obstacle for noting the 8 villages captured by NO-DO. César Casado de Pablos is the author of Las Vegas de San Antonio (1952) and Talavera la Nueva (1952) in Toledo and La Moheda (1944) in Cáceres; José Luis Fernández del Amo and Genaro Alas Rodríguez are the authors of the colonization village par excellence, Vegaviana. Among the 80 architects who worked for the INC, some of them were civil servants as Manuel Jiménez Varea, the author of Bernuy (1946), Valdeínigos (1950) and Alberche del Caudillo (1952) in Toledo and Cortijo de San Isidro (1948) in Madrid.

The included villages testified to the change from a historicist architecture (Bernuy and Cortijo de San Isidro) to the introduction of the modernity. On the first one, the collective prevailed over the residential individuality by the chronological proximity and influence of the reconstruction works undertaken by Regiones Devastadas. Otherwise, village were conceived later from the formal, linguistic and volumetric essentialization, the typological variation dependent on the programme and the difference seriation of housing.

In the first and second stages of the Tagus villages, architecture had a photogenic possibility of different expressivity. The initial houses configured larger architectural unities (by street alignment, continuity in the cornice, planity of the facade, arcades, etc.) while in the latest ones, the compositional game of their individualization in plant and facades (by turn, alternation of volumes and porosities, etc.) achieved the visual contrast of the shape and the plastic effect of the light. At this late stage, the cinematographic image recorded austerely such qualities, which would be carried out to lyric levels in photography.

\footnotetext{
${ }^{13}$ Translation by the authors: "los trazados más libres, la separación de circulaciones más decidida, la descomposición volumétrica y la introducción progresiva del vacío en muchos espacios públicos".

${ }^{14}$ Translation by the authors: "lo racional y el programa de la vivienda seriada".

${ }^{15}$ House in Toledo area [10: 28-29].
} 


\section{NO-DO - Image - Architecture}

Why one of the important achievements of which the Francoist Regime could boast was off the propaganda? Although this question remains open; in principle, two answers can be adduced:

1. NO-DO had a disinterest in the colonization or preferences in the constructive policy, since the Ministerio de Agricultura had its own Sección de Cinematografía to disseminate its activities and works. This is not true if one takes into account that besides the lacking news, with clear parallelisms with the agrarian documentary cinema, NO-DO produced 4 more extensive reports dedicated to the colonization in general to its Imágenes magazine: El camino andante (1955), the most outstanding for being a complete tour around the colonization works in the Tagus basin; En los campos de España (1956) and two compiling short films on the occasion of the Francoist commemoration of the 25 Years of Pace in the year 1964.

2. NO-DO was conditioned by its technical infrastructure, it is known and demonstrable [1: 18]. The scarce development of the communication routes in underdeveloped areas limited the shooting of the cinema operators in remote places on the Tagus River. Because of that, the travels of personalities (architects, official visits, etc.) were used both photographers [11: 193] and cameramen from Madrid. This is not the case in the news about the hydroelectric dams, where the correspondents (Fernando López Heptener ${ }^{16}$ ) provided the reports [12: 223].

Therefore, the second one seems to be one of the probable causes regarding the Tagus basin. This proves the reason of the limited attention that NO-DO paid to the villages before the cinema spectators. With this statement, it is not intended extrapolate the part to the whole, but it has been proved that is a fact happening regard throughout the country.

\section{Conclusions}

This study on the NO-DO adds a different perspective, unknown until now. First of all, since it focuses on architectural works which have not been paid attention in researches on the newsreel, more aimed to go in depth into the architectural emblem of the Regime (El Escorial, Valle de los Caídos, Alcázar of Toledo, etc.) and in which this subject is out of their reach. No particular attention has been paid to the cinematographic representation in the architectural researches on the villages either. Secondly, since it parts of the search for quantitative and analytical basis, which have not been used as research method to value the shown architecture.

We agree with Tranche and Sánchez-Biosca that in general NO-DO had an inefficient propaganda [1: 18], and specially in this case because it did not boast of the number of colonization villages built. However, their construction is one of the most prominent ventures, one of the achievements of the Regime in the modernization and development of depressed rural areas. NO-DO does not contradict the previous knowledge about the villages, but it covers up their true dimension and scale of action. Otherwise, the same cannot be said of the construction of the large hydroelectric

\footnotetext{
${ }^{16}$ Heptener was in charge of the NO-DO correspondent in Zamora, which with the headquarters in Madrid were the two unique existing offices in the centre of Spain in 1959. Heptener was above all a documentary filmmaker of the Saltos del Duero Company, later Iberduero, which combined with the institutionally correspondent of NO-DO, where he developed an intense activity.
} 
infrastructures of the mentioned Plan, which are subject of attention during the extensive existence of the newsreel.

Finally, it can be assumed than NO-DO, contrary to the rooted idea in the collective imaginary and in the specialized researches, in general does not make much diffusion and propaganda of the colonization villages. Specifically, management problems were more important than the propaganda intentions of the Franco dictatorship to the diffusion of the villages of the Tagus river basin on cinema screens. Nevertheless, NODO constitutes an audiovisual "built memory" on this subject with great relevance for our days, but poor for its time.

\section{Short resumes}

Josefina González Cubero. Architect (1986) and PhD (1996) in Architecture. Professor in the Department of Architectural Theory and Projects at the Escuela Técnica Superior de Arquitectura, University of Valladolid, Spain, since 1999. She has designed plans, projects and interventions aiming to enhance both the architectural heritage and cultural landscapes. Such works have been presented at many national and international conferences as well as exhibitions; they have also been included in numerous publications and have been awarded with various mentions and honours. Member (2005-2016) and coordinator (2010-2016) of Architecture and Cinema Research Group at the University of Valladolid. Collaborator researcher in the Centro de Estudos Arnaldo Araújo - Escola Superior Artística do Porto (FCT uRD 4041), Portugal, since 2007.

Alba Zarza Arribas holds a degree in Fundamentals of Architecture (2015) and Master in Architecture (2016) from the University of Valladolid, Spain. She is Visiting student researcher (Mobility Doctoral candidates UVa 2017) at Arnaldo Araújo Research Centre (FCT uRD 4041), Portugal. Currently, she is a $\mathrm{PhD}$ candidate, developing her research at the Centro de Estudos Arnaldo Araújo and the Department of Architectural Theory and Projects, University of Valladolid under a FCT PhD grant. Her research has been focused on the relations between architecture and cinema.

\section{References}

1. TRANCHE, R. R.; SÁNCHEZ-BIOSCA, V. 2000. NO-DO: el tiempo y la memoria. Madrid, Cátedra.

2. MEJÍAS, L. 1944. "El año español recogido por NO-DO”, Primer Plano, $n^{\circ} 168\left(2^{\text {nd }}\right.$ January): 29.

3. RODRÍGUEZ MARTÍNEZ, S. 1999. EI NO-DO, catecismo social de una época. Madrid, Editorial Complutense.

4. RODRÍGUEZ MATEOS, A. 2008. Un franquismo de cine. La imagen política del Régimen en el noticiario NO-DO (1943-1959), Madrid, Ediciones Rialp.

5. "Índices de la Revista Nacional de Arquitectura y de Arquitectura 1941-1983" (1984), Arquitectura (COAM), $\mathrm{n}^{\circ} 251$.

6. "Vegaviana: un poblado de colonización" (1958), Revista Nacional de Arquitectura, $\mathrm{n}^{\circ}$ 202: 1-12.

7. FERNÁNDEZ DEL AMO, J.L. 1995. "El arte en la fotografía de Kindel", in: FERNÁNDEZ DEL AMO, J.L. Palabra y obra. Escritos reunidos. Madrid, Colegio Oficial de Arquitectos de Madrid.

8. OYÓN BAÑALES, J.L. 2008. “¿Qué estudiaría yo hoy de la colonización del INC?”, in I. Luque Ceballos, C Guerrero Quintero, V. Perez Escolano et al. (eds.), Pueblos 
de colonización durante el franquismo: La arquitectura en la modernización del territorio rural. Sevilla, Junta de Andalucía-Consejería de Cultura - IAPH: 18-21.

9. PÉREZ ESCOLANO, V. 2008. "Una mirada arquitectónica a la modernización del territorio rural durante la colonización franquista", in I. Luque Ceballos et al. (eds.), op. cit:: 30.

10. TAMÉS ALARCÓN, J. 1954. Viviendas Rurales. Madrid, Instituto Nacional de Colonización.

11. FERNÁNDEZ DEL AMO, J.L. 1995. Palabra y obra. Escritos reunidos. Madrid, Colegio Oficial de Arquitectos de Madrid.

12. CEBRIÁN HERREROS, M. 1994. Cine documental e informativo de empresa: 50 años de producción de F. López Heptener en Iberduero y NO-DO. Madrid, Síntesis. 